\title{
Dam-Break analysis: proposal of a simplified approach
}

\section{Análise de ruptura de barragens: proposta de uma abordagem simplificada}

\author{
Carlo Lucca Coutinho Ungaretti Rossi ${ }^{1}$ (D), Marcelo Giulian Marques ${ }^{1}$ (D), Eder Daniel Teixeira ${ }^{1}$ (D), José Falcão de Melo ${ }^{2}$ (D), \\ Rute Ferla ${ }^{1} \&$ Maurício Dai Prá ${ }^{1}$ (D) \\ ${ }^{1}$ Instituto de Pesquisas Hidráulicas (IPH), Universidade Federal do Rio Grande do Sul (UFRGS) Porto Alegre, Rio Grande do Sul, Brasil \\ ${ }^{2}$ Laboratório Nacional de Engenharia Civil Lisboa, Portugal \\ E-mails: rossi.carlolucca@gmail.com (CLCUR),mmarques@iph.ufrgs.br(MGM), eder.teixeira@ufrgs.br (EDT),jfmelo@Inec.pt (JFM), \\ ruteferla@hotmail.com (RF),mauricio.daipra@ufrgs.br (MDP)
}

Received: April 16, 2020 - Revised: October 01, 2020 - Accepted: November 09, 2020

\begin{abstract}
Simplified methods are useful alternatives for prior analysis of the effects of dam rupture and can guide the decision-making process for carrying out more complete studies. In this context, a new simplified approach is presented, which enables the analysis of aspects from dam rupture of earthen dams that failed due to overtopping, considering dam height and reservoir volume as input data. Hypothetical cases were analyzed applying dam-break hydrodynamic simulations, which results allowed the development of equations capable of estimating peak flow attenuation and peak discharge arrival time along the downstream valley. The proposed approach was applied in a hypothetical case study (15 m high dam and $17 \mathrm{hm}^{3}$ reservoir volume), obtaining results close to those achieved through other methods, especially in case of estimating the maximum discharges throughout the downstream valley, where the average differences between the results of the methods were of the order of $15 \%$.
\end{abstract}

Keywords: Dam-break; Simplified methods; Flood wave; Flood routing.

\section{RESUMO}

Métodos simplificados são alternativas úteis para análise prévia dos efeitos da ruptura de barragens, podendo orientar a tomada de decisão da realização de estudos mais completos. Nesse contexto, propõe-se uma nova abordagem simplificada para análise de aspectos da ruptura de barragens de terra, cuja falha ocorre por galgamento, a partir da altura da barragem e do volume do reservatório como dados de entrada. Casos hipotéticos de ruptura foram analisados por meio de simulações hidrodinâmicas, cujos resultados permitiram desenvolver equações capazes de estimar o amortecimento da vazão de pico e o tempo de chegada da vazão máxima no vale a jusante. A abordagem proposta foi aplicada em estudo de caso hipotético (em uma barragem com $15 \mathrm{~m}$ de altura e $17 \mathrm{hm}^{3}$ de volume no reservatório), obtendo-se resultados próximos dos alcançados por meio de outros metodos, especialmente na estimativa da vazão máxima no vale a jusante, onde as diferenças médias entre os resultados dos métodos considerados foram da ordem de $15 \%$.

Palavras-chave: Ruptura de barragens; Métodos simplificados; Onda de cheia; Propagação de vazões. 


\section{INTRODUCTION}

Although dams have been used for millennia, only in the XX century significant technological advances enabled the construction of safe developments. Despite this evolution and studies performed to ensure dam safety during design, construction and operation, risk of failure cannot ever be made null. Proving that fact, dam failures eventually occurred with severe consequences such as St. Francis, Malpasset and Vajont (Jansen, 1983). One of the most documented dam failures in history, the Teton Dam failure, in 1976, can be considered the trigger for the first issuance of regulations imposing dam failure analysis and forecasting of downstream flood waves, inundation maps and potential hazards (Wahl, 2010). Due to past events, nowadays it is perceived that every dam represents a source of potential hazard to the downstream valley. Flood waves from dam failures possess high destructive potential, which can cause massive economic losses, fatalities, social and environmental damages when reaching population and structures along its path, as seen in the last two major tailing dams accidents in Brazil: Fundão (Mariana, MG), in 2015, and Barragem I (Brumadinho, MG) in 2019. These are good examples of accidents with enormous proportions and big coverage by the media. However, there are countless other dams with smaller dimensions collapsing every year, which must also be taken into account. Just in the current year, in Brazil, one can mention dam failures in Currais (Meio Norte, 2020), in Sairé (G1 Caruaru, 2020) and in Perdizes (Elisa \& Campos, 2020). Other examples around the world can also be found, such as the accidents of Edenville Dam (Ellison, 2020), Stanford Dam (Matheny, 2020), Bear Lake Dam (Ferretti, 2020) and a dam in Blue Nile state of Sudan (Arab News, 2020).

Dam safety regulations were issued in Brazil in 2010, with Law 12.334/2010, which instituted the National Dam Safety Policy (PNSB). This legislation represents a paradigm shift in Brazilian dam safety environment. Previously, several safety aspects were evaluated solely based on experience, while now they are confirmed and institutionalized by law (Ferla, 2018). One of the biggest changes imposed by the dam safety law is the mandatory preparation of a Dam Safety Plan. Among its various requirements, it imposes the elaboration of Emergency Action Plans (EAP) for dams classified as high risk (classification includes structural and operational aspects, dam technical characteristics, conservation condition and fulfillment of the Dam Safety Plan). EAPs are complex documents which, despite the technical background, should be written so that any layman reader can understand them (Sampaio, 2016). Considering all required EAPs' contents, the identification of the effects along the downstream valley arising from a possible structure failure stands out. In this context, dambreak studies become extremely important, as they allow the estimation of specific parameters closely linked to the potential damages caused by the dam rupture generated flood wave, such as maximum reached water levels and flow velocities along the downstream valley.

Dam-break studies backing EAPs should be carried out based on coherent input data, so that results are as close as possible to most likely occurring scenarios. However, data such as topobathymetry is very often unavailable and obtaining such data may be too expensive or time-consuming. Also, reliability issues might be raised, normally deriving from the many uncertainties involved, such as: type of rupture, downstream valley conditions during the rupture, effects of the rupture on topography, geology and hydraulic conditions. These dilemmas represent a major challenge for dam owners and inspection agents for complying with deadlines established in the legislation, given the large number of involved existing dams, for which, generally, there is no data for these analyzes. Due to recent regulations in Brazil, challenges in balancing the needed time and costs to acquire the necessary data to perform mandatory dam-break studies are similar to those already felt in the past in other countries with older similar regulations. According to Grimaldi \& Poggi (2010), in Italy there is a significant number of dams considered small and medium whose detailed rupture analysis would involve high costs and considerable time. Thus, regional authorities are evaluating the possibility of adopting simpler methods requiring less data and time to complete, seeking to reach acceptable results, sufficiently close to those obtained with more sophisticated methods, namely computational hydrodynamic dam-break simulations.

In addition to the aforementioned challenges, the last two major accidents in Brazil over an interval of four years, where the loss of human life and environmental damage were very significant, indicate the country's need to move forward in dam safety matters. On that note, it is necessary that, at least, preplanning emergency actions for dam rupture can be produced in quicker and more efficient way. In this context, simplified methods emerge as interesting options, considering their expeditious applicability, small amount of input data and credible results. These methodologies can, therefore, be used for dam rupture effects preliminary assessment, determining the potentially affected areas and reducing the number of complete studies to only the most critical cases. Also, simplified methods can be used as a tool to determine areas where topographic data should be surveyed thoroughly, enabling a reduction of costs in complete studies.

There are several simplified methods developed over the years that allow the inundation zones assessment (e.g. Cunge, 1969; Wetmore \& Fread, 1981; Melo, 2015). Nevertheless, there is still no consensus on the use of these simplified approaches, despite the general acceptance that simplified approaches should not be used for the EAP elaboration of high risk dams. Even so, in recent years, some authors have been analyzing the effectiveness of these types of simplified methods by comparing the results with those obtained using hydrodynamic numerical simulations (e.g. Melo, 2015; Teixeira et al., 2016; Ferla et al., 2017; among others). In general, these studies compare water level results and associated inundation zones determined by means of simplified methods against those produced with the use of HEC-RAS or similar software. However, the number of published studies comparing the results from simplified and numerical methods is not very significant. So it is not yet possible to make definitive statements about the effectiveness of simplified methods (Ferla, 2018).

According to Agência Nacional de Águas (2017), there are 24,092 dams registered by inspection agencies in Brazil. Among them, 4,510 dams have enough information to state that they fall under the PNSB. For these dams, PNSB's instruments will be applied, especially those referring to the existence of Dam Safety Plan and its components (inspections, periodic review and EAP). 
Due to the terms established by PNSB, most registered dams need to present an Emergency Action Plan. In addition, Brazil has numerous other dams of smaller sizes, involving lower potential hazard than larger dams, which must be analyzed to assess whether or not they must have EAPs in case of failure.

Bearing in mind the number of dams in Brazil that will require the drafting of EAPs and dam-break studies (dams covered by Law 12.334), simple and expeditious methodologies that allow preliminary assessment of the effects of a possible rupture, or even delineate smaller study areas, could be important tools for the evolution of the dam safety scenario in the country. Furthermore, simplified methodologies' importance can be highlighted due to the numerous small dams in the country (not covered by the law), but still having considerable associated potential hazard and which, according to Agência Nacional de Águas (2016a), can be evaluated by simplified methodologies, depending on inspection authorities.

Several studies were carried out to verify the efficiency of simplified methods, being consensual the adequacy of its use for preliminary estimation of inundation zones due to dam ruptures. However, conclusions derive mostly from analyses of large dams, raising questions on their applicability to small and medium sized dams, which are highly representative in Brazil.

Therefore, the development of research enabling existing methods validation, or even establishment of simpler and faster methods, is highly convenient for the advance of the dam safety framework. Thus, the present paper aims at creating a new approach for analyzing dam-break cases using limited dataset. The new approach's main target is to expeditiously assess peak flow attenuation and peak discharge arrival time along the downstream valley, having smaller dams as its main focus, for which simplified methods can be applied (Agência Nacional de Águas, 2016a).

\section{DAM-BREAK STUDIES}

Dam-break studies are important in determining the risks of fatalities in addition to economic, social and environmental damages. A complete dam-break study, according to Agência Nacional de Águas (2016a), should simulate several rupture scenarios, providing the following information: downstream valley characterization; flood inundation map; Self-Rescue Zones characterization (ZAS); and escape routes.

Information to carry out this type of study varies according to each corresponding area specificities. However, for most studies, in addition to dam characterization itself, information regarding reservoir volume, probable dam breach formation, downstream valley topography, downstream valley affected population and terrain roughness is also necessary.

Currently, due to modern computer processing capabilities, dam-break hydraulic and hydrodynamic software that have been developed, tested and improved over the years can easily be accessed, such as HEC-RAS (U.S. Army Corps of Engineers, 1995), DAMBRK (Fread, 1991), FLDWAV (Fread \& Lewis, 1998) and LISFLOOD (Bates \& De Roo, 2000). In general, most of these software require the following input data: downstream valley Manning coefficient; breach configuration; reservoir volume; downstream valley topography and; set of equations and simplifications considered for flood wave propagation (Tschiedel \& Paiva, 2018).
Amongst the multiple software approaches available for dam-break effects assessment, Wahl (2010) points out three main modeling strategies developed since 1970, namely: (I) directly predict the breach outflow hydrograph and then use one of the available models to route the flood wave downstream; (II) parameterize the breach so that its evolution over time can be easily represented, allowing the breach outflow hydrograph to be determined by combining the breach formation with a spillway equation or other appropriate model; (III) use a combined model that simulates erosive processes associated with hydraulic processes to determine the breach and the outflow hydrograph flowing through it.

The most popular and used approach consists in the prediction of breach evolution, while the simplest one corresponds to the direct prediction and routing of breach outflow hydrograph. The approach involving erosion processes is only applied to earthen dams and demands a considerable amount of data concerning dam's material. In addition, the produced rupture hydrograph with this last approach is very sensitive to the input data uncertainty, making this strategy less suitable than the simpler ones.

\section{SIMPLIFIED METHODS}

Currently, numerous software and simplified methods capable of reproducing the behavior of a dam breach are available. According to Ferla (2018), the interest in developing simplified methods for determining dam failure characteristics has been known for at least 40 years. Melo et al. (2015) highlight the use of simplified methods for dam failure due to the lack of required input data for more sophisticated methods, such as terrain data, dam failure modes, hydraulic and hydrological data, among others. However, it is emphasized that the use of simplified methods should not subsidize the preparation of an Emergency Action Plan (EAP) for high hazard dams, since the results from these methods do not have the degree of detail necessary for the plan preparation. On the other hand, Agência Nacional de Águas (2016a) raises the possibility for smaller dams to be evaluated by means of simplified methods.

Hydrodynamic models, which are the usual choice for performing dam-break studies, seek to solve the complete Saint-Venant equations using numerical methods. Simplified approaches seek to propagate the rupture hydrograph, abridging the complexity of the problem without significant loss of results' accuracy (Ferla, 2018).

Muskingum-Cunge (Cunge, 1969) and the Simplified Dam-Break Flood Modelling (Melo, 2015) are two of the existing methods that can be used to assess impacts from dam failure. These methods correspond, respectively, to a very widespread approach for routing hydrographs in rivers and channels (Ferla, 2018), which consists of a simplification of Saint-Venant's equations, and a set of simplified procedures developed by Laboratório Nacional de Engenharia Civil (2014) for determining associated potential hazard of dams.

In general, simplified methods for dam-break analysis use the strategy of predicting the outflow breach hydrograph and then routing it downstream. The characteristics of the hydrograph that must be predicted are the peak outflow, the time necessary to reach the peak and the hydrograph's shape, which is related to 
the volume of the hydrograph. These aspects have been object of several studies (such as Wetmore \& Fread, 1981; Froehlich, 2016), which produced a wide range of options and alternatives to estimate the breach hydrograph's characteristics.

Peak outflow: several researchers have developed peak flow regression equations from historic dam failure data. These formulations were derived from data for earthen, zoned earthen, earthen with impervious core and rockfill dams only (U.S. Army Corps of Engineers, 2014).

Froehlich (2016) indicates that the equations proposed by Froehlich (1995), Webby (1996) and Azimi et al. (2015) present, in general, good results. The equation developed by Ferla (2018) should also be highlighted because the author restricted the database to overtopping cases of earthen and rockfill dams. The formulas developed by these authors are presented in Table 1.

Time to reach the peak: Wahl (2004) states that the breach hydrograph peak time is close to the breach formation time, except for relatively small reservoirs where the peak can occur before the end of breach formation. There are several regression equations based on historic dam failure data to estimate time of the breach formation. Among existing equations, Wahl (2004) indicates the Von Thun \& Gillette (1990) and Bureau of Reclamation (1988) equations as underestimating the breach formation time, providing more critical scenarios than the other equations. A shorter time to reach the peak prompts in shorter time for evacuation downstream. Table 2 presents these authors' equations.

Hydrograph's shape: several studies identify most influential aspects influencing rupture hydrograph's shape (Kuhlkamp, 2016; Souza, 2016; Kim \& Sanders, 2016; Rocha, 2015; Alvarez et al., 2017; Hooshyaripor et al., 2017; among others), namely the configuration of the breach, the Manning coefficient and the topography.

Table 1. Peak outflow equations.

\begin{tabular}{lcc}
\hline \multicolumn{1}{c}{ Author } & \multicolumn{1}{c}{ Equation } & Eq. $\mathbf{n}^{\mathrm{o}}$ \\
\hline Froehlich (1995) & $\mathrm{Q}_{\mathrm{p}}=0.607 \mathrm{~V}_{\mathrm{r}}^{0.295} \mathrm{H}_{\mathrm{w}}{ }^{1.24}$ \\
Webby (1996) & $\mathrm{Q}_{\mathrm{p}}=0.0443 \sqrt{\mathrm{g} \mathrm{V}_{\mathrm{r}}^{0.365} \mathrm{H}_{\mathrm{w}}{ }^{1.405}}$ \\
Azimi et al. (2015) & $\mathrm{Q}_{\mathrm{p}}=0.0166 \cdot \sqrt{\mathrm{g} \mathrm{V}} \cdot \mathrm{H}_{\mathrm{w}}$ \\
Ferla (2018) & $\mathrm{Q}_{\mathrm{p}}=\left(\mathrm{V}_{\mathrm{r}}^{0.56} \mathrm{H}_{\mathrm{w}}{ }^{0.45}\right) / 3$
\end{tabular}

$\mathrm{Q}_{\mathrm{p}}$ is equivalent to the peak flow of the rupture hydrograph $\left(\mathrm{m}^{3} \mathrm{~s}^{-1}\right)$; $\mathrm{V}_{\mathrm{r}}^{\mathrm{p}}$ is equivalent to the reservoir's volume $\left(\mathrm{m}^{3}\right) ; \mathrm{H}_{\mathrm{w}}$ is equivalent to the water height at the moment of the rupture $(\mathrm{m})$; $\mathrm{g}$ is equivalent to the gravity $\left(\mathrm{m} \mathrm{s}^{-2}\right)$.

Table 2. Equations for the prediction of the time to reach the peak outflow.

\begin{tabular}{lcc}
\hline \multicolumn{1}{c}{ Author } & Equation & Eq. $\mathbf{n}^{\circ}$ \\
\hline $\begin{array}{l}\text { Bureau of Reclamation (1988) } \\
\text { Von Thun \& Gillette (1990): erodible }\end{array}$ & $\mathrm{t}_{\mathrm{p}}=0.033 \mathrm{H}_{\mathrm{w}}$ \\
$\begin{array}{l}\mathrm{t}_{\mathrm{p}}=0.015 \mathrm{H}_{\mathrm{w}} \\
\text { materials }\end{array}$ \\
$\begin{array}{l}\text { Von Thun \& Gillette (1990): resistant } \\
\text { to erosion }\end{array}$ & $\mathrm{t}_{\mathrm{p}}=0.02 \mathrm{H}_{\mathrm{w}}+0.25$ \\
\hline $\mathrm{t}_{\mathrm{p}}$ is equivalent to the time to reach the peak (h).
\end{tabular}

Predicting the breach outflow hydrograph's shape, without using a predetermined breach evolution approach and having a software estimating it, is quite complex. For this reason, simplified forms of hydrographs have been used. In general, adopted shapes are: triangular with the peak at $\mathrm{t}_{\mathrm{p}}=0$; triangular with the peak at $\mathrm{t}_{\mathrm{p}} \neq 0$ and parabolic decay.

\section{MATERIALS AND METHODS}

The study's main goal concerned the development of an approach to assess some of dam-break flood wave key hydraulic parameters. The adopted strategy consisted on performing computational dam-break simulations for several sets of predefined conditions in which the main parameters were changed. Then, the results were analyzed in order to deduce regression equations properly describing the peak flow attenuation and the peak discharge arrival time for each set of similar situations. The developed method was finally tested in a hypothetical case study.

The research was divided in six phases: (I) establishing the characteristics of dams to be studied; (II) scenarios and conditions; (III) breach outflow hydrographs; (IV) dam-break simulations; (V) results processing; (VI) case study.

\section{Characteristics of the studied dams}

Characteristics of the dams (height and the reservoir's volume) used in the development of the simplified approach were carefully chosen in order to allow a significant application range.

The chosen dam heights and reservoir volumes determine the covered size of the dams. For the concept of dam size, the one adopted by Agência Nacional de Águas (2016b) was considered, which is based on French standards definition (ICOLD Bulletin No. 157) and on Portuguese legislation. It derives from a quantitative factor X, Equation 8, and a qualitative range of classification, presented in Table 3.

$$
\mathrm{X}=\mathrm{H}_{\mathrm{d}}^{2} \cdot \sqrt{\frac{\mathrm{V}_{\mathrm{r}}}{10^{6}}}
$$

Where: $\mathrm{H}_{\mathrm{d}}$ is the dam height $(\mathrm{m}) ; \mathrm{V}_{\mathrm{r}}$ is the volume of the reservoir $\left(\mathrm{m}^{3}\right)$.

Relative and cumulative frequencies were established to describe the current characteristics of Brazilian dams regarding dam heights and reservoir volumes. This was done taking into account the dams registered by the Brazilian Dam Safety Report (Agência Nacional de Águas, 2017) that possess both characteristics. Figure 1 presents the relative and cumulative frequencies concerning dam heights, while Figure 2 presents the same information concerning reservoir volume.

From these figures, approximately $75 \%$ of registered dams have height below $15 \mathrm{~m}$, while $72 \%$ have a volume below $3 \mathrm{hm}^{3}$. In

Table 3. Dams' size classification based on to the factor $X$ value.

\begin{tabular}{cc}
\hline Dams' size & Limits for the classification \\
\hline Small & $\mathrm{X} \leq 400$ \\
Medium & $400<\mathrm{X} \leq 1000$ \\
Large & $\mathrm{X}>1000$ \\
\hline
\end{tabular}


other words, most of the registered dams possess characteristics not covered by the law and could be evaluated through simplified methods.

Therefore, considering the current characteristics of Brazilian dams, a set of four pre-defined heights (varying from $5 \mathrm{~m}$ to $30 \mathrm{~m}$, which corresponds to $60 \%$ of the dams) and another set of four pre-defined volumes (varying from $5 \times 10^{6} \mathrm{~m}^{3}$ to $50 \times 10^{6} \mathrm{~m}^{3}$, which corresponds to $10 \%$ of the dams) were chosen for this analysis. The combination of both sets of characteristics was made so that the method covers all three size categories. Thus, twelve dams with different characteristics, as shown in Table 4, were considered. The selection is composed of five Small dams, four Large dams and three Medium dams.

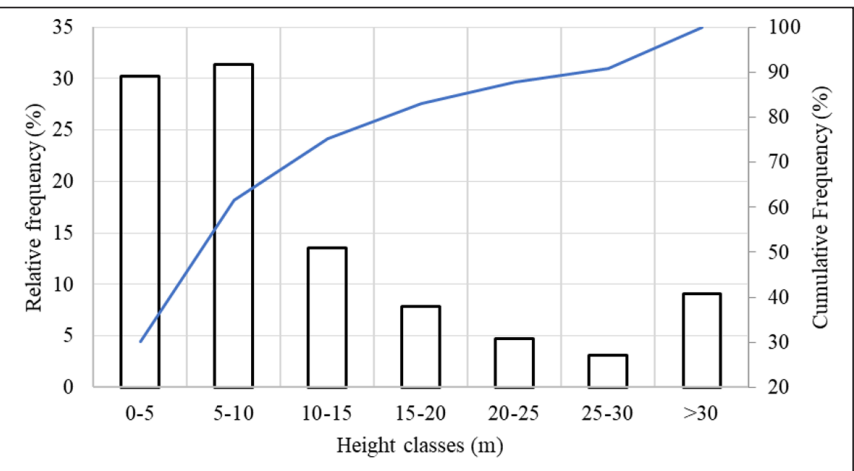

Figure 1. Brazilian dam height relative and cumulative frequencies.

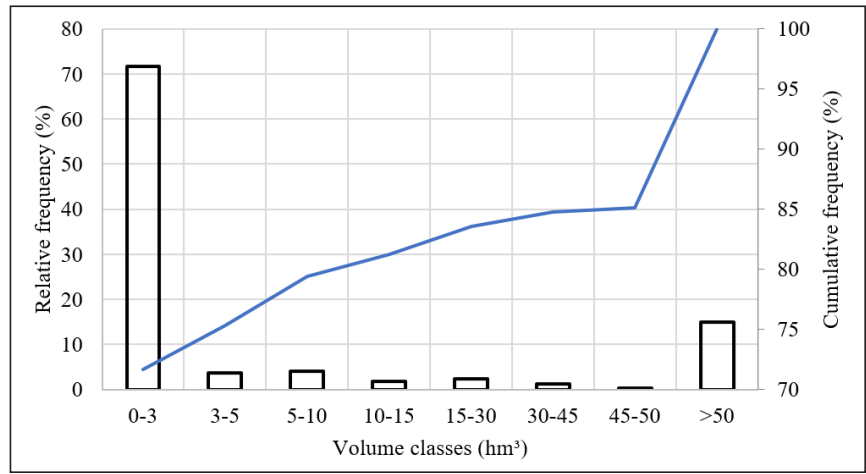

Figure 2. Brazilian reservoir volume relative and cumulative frequencies.

Table 4. Characteristics of the selected dams.

\begin{tabular}{lcccc}
\hline Dam & $\mathbf{H}_{\mathbf{d}} \mathbf{( m )}$ & $\mathbf{V}_{\mathbf{r}}\left(\mathbf{1 0}^{\mathbf{6}} \mathbf{m}^{\mathbf{3}}\right)$ & $\mathbf{X}$ & Classification \\
\hline BI & 5 & 5 & 56 & Small \\
BII & 10 & 5 & 224 & Small \\
BIII & 15 & 5 & 503 & Medium \\
BIV & 5 & 10 & 79 & Small \\
BV & 10 & 10 & 316 & Small \\
BVI & 15 & 10 & 712 & Medium \\
BVII & 30 & 10 & 2,846 & Large \\
BVIII & 5 & 20 & 112 & Small \\
BIX & 10 & 20 & 447 & Medium \\
BX & 15 & 20 & 1,006 & Large \\
BXI & 30 & 20 & 4,024 & Large \\
BXII & 30 & 50 & 6,364 & Large \\
\hline
\end{tabular}

\section{Scenarios and conditions}

Zhang et al. (2007) point out earthen dams as being the type most subject to failure. Thus, it was decided to consider only earthen dams in this study, the adopted failure mechanisms and remaining aspects having been selected based on this choice. Overtopping was considered for the rupture mechanism, since it is recognized as being the most frequent cause of ruptures (Imbrogno, 2014).

Among the rupture scenarios presented by Agência Nacional de Águas (2016a), the most unfavorable rupture was chosen, which assumes the occurrence of rapid and total ruptures, potentially generating more serious consequences. Additionally, an overtopping head of $0,15 \mathrm{~m}$ over the crest of the dams was adopted, this assumption being accepted as the minimum height to start the breach formation (Agência Nacional de Águas, 2016a).

\section{Breach outflow hydrographs}

To characterize the breach outflow hydrograph, one must estimate: the peak outflow; the peak time; and the hydrograph shape.

Considering a conservative approach, the peak outflow corresponds to the maximum calculated flow among the equations proposed by Froehlich (1995), Webby (1996), Azimi et al. (2015) and Ferla (2018). Conversely, the peak time will correspond to the minimum time given by the equations of Bureau of Reclamation (1988) and Von Thun \& Gillette (1990). Regarding the hydrograph shape, it was assumed a triangular shape with the peak conservatively at $t_{\mathrm{p}} \neq 0$.

\section{Dam-break simulations}

The simulations were performed in a prismatic hypothetical channel. This channel is $500 \mathrm{~km}$ long, allowing a prolonged downstream analysis of the flood-wave. Only one channel slope was considered: a moderate slope of $0.001 \mathrm{~m} / \mathrm{m}$ has been set, based on the information presented by Washington State Department of Ecology (2007). The cross section is trapezoidal with lower width and height large enough so that the maximum flow does not lead to channel overtopping. For that reason, a lower width of $85 \mathrm{~m}$ and lateral wall slopes of $1 \mathrm{~V}: 2 \mathrm{H}$ were adopted.

Since the study does not aim to assess the influence of downstream valley sections roughness, a unique roughness was assumed for all sections. As shown by Fema (Federal Emergency Management Agency, 2001), adopting a roughness aggregating both main channel behavior and floodplain is required. In the studies presented by Fema (Federal Emergency Management Agency 2001), a Manning coefficient between 0.04 and $0.05 \mathrm{~m}^{-1 / 3} \mathrm{~s}$ was adopted for the downstream valleys. Thus, it was decided to adopt a roughness coefficient of $0.042 \mathrm{~m}^{-1 / 3} \mathrm{~s}$, slightly higher than values normally adopted for main channels, but close to the lower limit used for floodplains.

Additionally, simulations were carried out using the HECRAS software, version 5.0.7., which is widely accepted in technical and scientific environments. This software is one of the most used in dam-break studies, being accepted as the current state of the 
art (Ferla, 2018). Choosing between 1D and 2D models shall be judicious as there are cases where $2 \mathrm{D}$ models can produce better results than $1 \mathrm{D}$ models, as well as cases where the opposite is true (U.S. Army Corps of Engineers, 2016). However, based on the information available and the conditions adopted for the research in which the simplified aspect is key, a 1D model was chosen to perform the simulations.

As previously mentioned, among the described available simulation strategies, the most used one corresponds to the predetermined evolution of the breach. However, there is no clear reason for opting for this approach compared to a simpler approach, such as the routing of the simplified breach hydrograph, since both encompass many uncertainties. Therefore, for this study, the simplest strategy was chosen precisely due to the intended simplified approach relying on very limited quantity of data.

To avoid instabilities in HEC-RAS model, an initial water level in the channel of approximately $1.3 \mathrm{~m}$ was assumed. This water height corresponds to an initial discharge (base flow) of approximately $100 \mathrm{~m}^{3} \mathrm{~s}^{-1}$. Concerning the downstream valley discretization, cross sections were considered with intervals of $350 \mathrm{~m}$. Time discretization assuming one minute intervals was considered.

\section{Results processing}

The proposed approach aims at providing a simplified approximation of peak flow attenuation and peak discharge arrival times. The results analysis has been conducted by means of dimensional analysis. This type of analysis enables future comparison of current results with others from simulations covering different types of channels cross sections, slopes, etc. Additionally, this analysis provides an overview of the differences between the different hydrographs and methods.

An aspect to be highlighted derives from the fact that most peak outflow equations award more importance to the parameter water height at the moment of rupture. Considering that aspect and the characteristics of selected dams, the established relationships were grouped by dams' heights. In other words, it is assumed that dams with the same height have similar behaviors.

\section{Case study}

A case study was carried out to evaluate the proposed approach, in which results from hydrodynamic numerical simulation, considered as the reference scenario, are compared with both the results from the developed simplified approach and those from the methodology Simplified Dam-Break Flood Modeling proposed in Melo (2015). This analysis enables an accuracy and efficiency verification of both simplified methods concerning maximum discharges, water heights and peak discharge arrival time.

This case study considers a hypothetical dam with $15 \mathrm{~m}$ and $17 \mathrm{hm}^{3}$ of reservoir volume. As for the downstream valley, eight real topobathymetric sections over $43 \mathrm{~km}$, named section $\mathrm{A}$ to $\mathrm{H}$, were evaluated (Table 5 and Figure 3). The valley has an average section width of $630 \mathrm{~m}$ and an average thalweg slope of $0.0008 \mathrm{~m} \mathrm{~m}^{-1}$. Considering the valley characteristics, roughness coefficients of
Table 5. Downstream valley's cross sections characteristics.

\begin{tabular}{cccc}
\hline Section & $\begin{array}{c}\text { Average width } \\
(\mathbf{m})\end{array}$ & $\begin{array}{c}\text { Thalweg slope } \\
\left(\mathbf{m . m}^{-1}\right)\end{array}$ & $\begin{array}{c}\text { Distance from } \\
\text { the dam }(\mathbf{m})\end{array}$ \\
\hline A & 850 & 0.001 & 10,889 \\
B & 600 & 0.0004 & 16,444 \\
C & 800 & 0.0009 & 20,667 \\
D & 480 & 0.0011 & 27,111 \\
E & 400 & 0.001 & 33,778 \\
F & 540 & 0.001 & 36,667 \\
G & 600 & 0.0002 & 38,889 \\
H & 760 & 0.0003 & 43,556 \\
\hline
\end{tabular}

$0.03 \mathrm{~m}^{-1 / 3} \mathrm{~s}$ for the main channel and $0.08 \mathrm{~m}^{-1 / 3} \mathrm{~s}$ for the floodplain outer banks' area were adopted. All characteristics considered for the case study are within the hypothetical ones used for establishing the hereby proposed simplified approach.

The hydrodynamic simulation was carried out with the HEC-RAS 1D considering the simplified breach hydrograph routing. Overtopping failure is triggered when water level reaches $0.15 \mathrm{~m}$ over dam's crest. Breach outflow hydrograph was obtained considering the same process of simplified approach development. As an initial condition, at the moment of rupture, a discharge $\left(Q_{0}\right)$ of $1,098 \mathrm{~m}^{3} \mathrm{~s}^{-1}$ flowing along the downstream valley was assumed, corresponding to the ten year return period flood for the region. Regarding space discretization, cross sections were placed every $900 \mathrm{~m}$ along the channel. One minute time intervals were considered in the computational model.

\section{RESULTS AND DISCUSSION}

Firstly, breach hydrographs characteristics used to perform the simulations are presented. Then results obtained for peak flow attenuation and peak discharge arrival time. Finally, case study results are described and discussed.

\section{Breach hydrographs}

Peak flows were determined as the maximum flow among the four presented methods. Table 6 shows maximum peak flows and its corresponding equation. Peak flows vary from $863 \mathrm{~m}^{3} \mathrm{~s}^{-1}$ (Dam BI) to $11,085 \mathrm{~m}^{3} \mathrm{~s}^{-1}$ (Dam BXII), corresponding respectively to the smallest and largest considered dams.

Regarding breach hydrographs peak times (presented in Table 7), the method providing the most critical scenario was Von Thun \& Gillette (1990) for erodible materials, which is characterized by fast ruptures. For $5 \mathrm{~m}$ dams, peak is reached with 0.08 hours. For $10 \mathrm{~m}$ and $15 \mathrm{~m}$ dams, peak is reached after 0.15 and 0.23 hours, respectively. Lastly, for $30 \mathrm{~m}$ dams, peak is reached 0.45 hours after start of breach formation.

A triangular shaped hydrograph was adopted as, according with literature, it is the most commonly considered for these modeling strategies. Therefore, breach hydrograph base time was estimated considering the peak time and the necessary time for reservoir to drawdown after reaching the peak outflow. These times vary from 1.43 (Dam BVII) to 7.4 hours (Dam BVIII). 

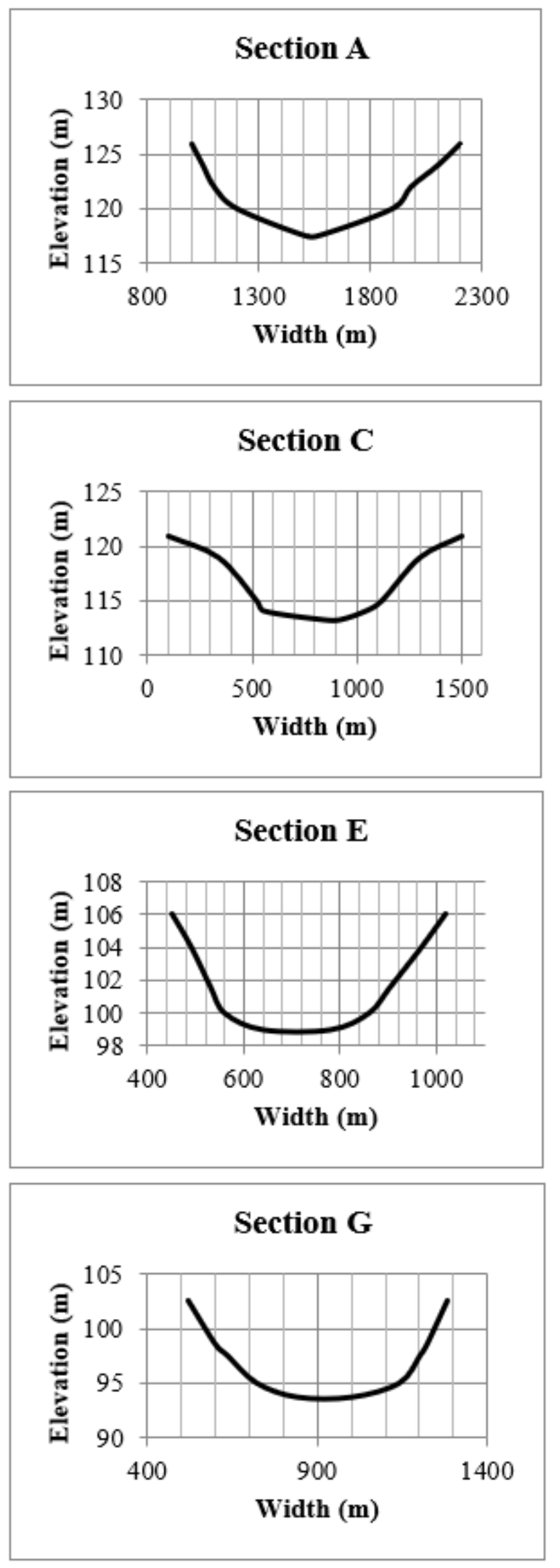

Figure 3. Case study downstream valley's cross sections.
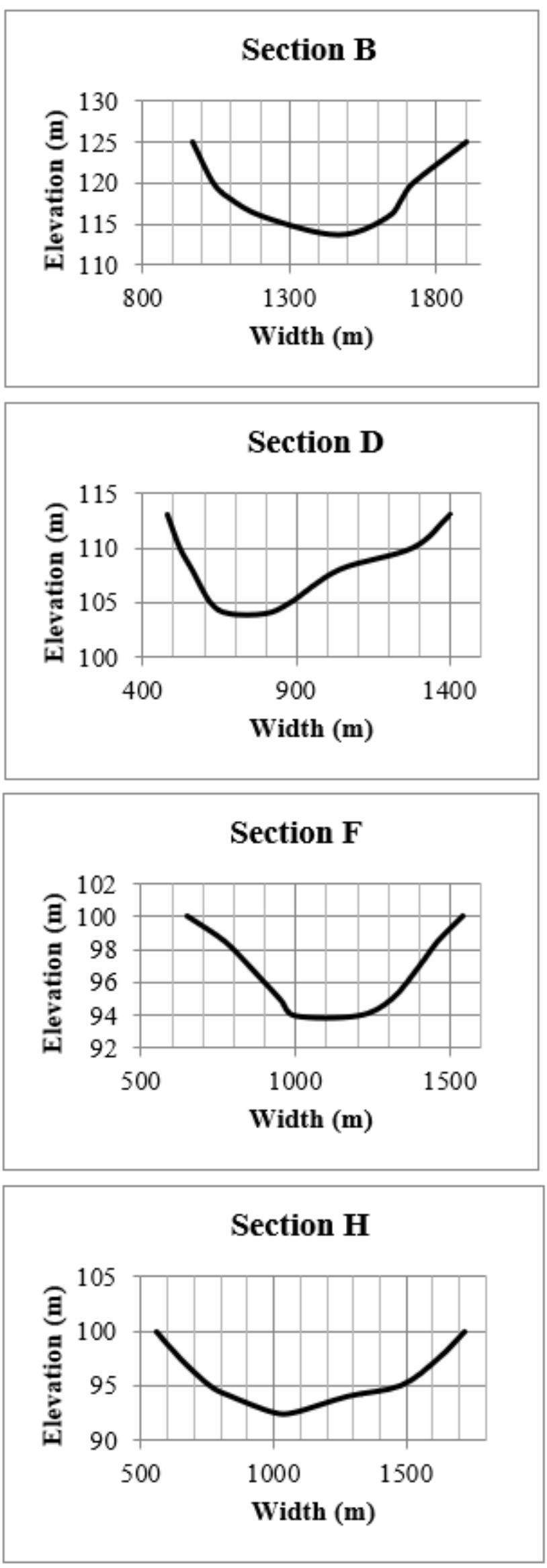


\section{Peak flow attenuation}

Peak flow attenuation was analyzed relating maximum discharges at each section $\left(Q_{\text {max }}\right)$ with corresponding breach peak outflows and downstream valley base flow $\left(\mathrm{Q}_{0}\right)$. Figures 4-7 show this relationship evolution for dams 5, 10, 15 and $30 \mathrm{~m}$ high, respectively.

A similar behavior was found across all dams' groups, a larger attenuation being noticeable in the first 50 to $100 \mathrm{~km}$ from dam section, ranging from 37\% (Dam BVIII) to 85\% (Dam BVII). Further downstream the attenuation between successive sections decreases, tending progressively to a steady behavior. In the downstream most section, attenuation varies between $76 \%$ (Dam BVIII) and 95\% (Dam BVII).

Another factor noticed in all groups is that the lowest flow attenuation corresponds to the dam with the largest reservoir. This result makes sense, as the downstream channel is the same for all dams, it would be expectable a greater difficulty in attenuating the larger water volumes.

From the behavior presented by each dams' group, one can infer that the bigger dam height, the bigger the peak flow attenuation. In other words, there was a more significant attenuation for higher flows, which are obtained with higher dams. In the downstream most section, peak flow attenuation for dams $30 \mathrm{~m}$

Table 6. Peak outflows and respective methods of the breach hydrographs for each dam.

\begin{tabular}{lccc}
\hline Dam & $\mathbf{H}_{\mathbf{d}}(\mathbf{m})$ & $\begin{array}{c}\text { Peak outflow } \\
\left(\mathbf{m}^{\mathbf{3}} \mathbf{s}^{-1}\right)\end{array}$ & Methodology \\
\hline BI & & 863 & \\
BIV & 5 & 1,179 & Ferla (2018) \\
BVIII & & 1,611 & \\
\hline BII & \multirow{2}{*}{10} & 1,262 & Ferla (2018) \\
BV & 1,724 & Ferla (2018) \\
BIX & & 2,360 & Azimi et al. (2015) \\
\hline BIII & & 1,761 & Webby (1996) \& \\
& \multirow{2}{*}{15} & & Azimi et al. (2015) \\
BVI & & 2,491 & Azimi et al. (2015) \\
BX & & 3,523 & Azimi et al. (2015) \\
\hline BVII & & 5,965 & Webby (1996) \\
BXI & 30 & 7,683 & Webby (1996) \\
BXII & & 11,085 & Azimi et al. (2015) \\
\hline
\end{tabular}

Table 7. Peak time and Base time of the breach hydrographs.

\begin{tabular}{|c|c|c|c|}
\hline Dam & $H_{d}(m)$ & Peak time (h) & Base time (h) \\
\hline $\mathrm{BI}$ & & & 3.72 \\
\hline BIV & 5 & 0.08 & 5.22 \\
\hline BVIII & & & 7.40 \\
\hline $\mathrm{BII}$ & & & 2.70 \\
\hline BV & 10 & 0.15 & 3.72 \\
\hline BIX & & & 5.20 \\
\hline BIII & & & 2.08 \\
\hline BVI & 15 & 0.23 & 2.73 \\
\hline $\mathrm{BX}$ & & & 3.65 \\
\hline BVII & & & 1.43 \\
\hline BXI & 30 & 0.45 & 1.72 \\
\hline BXII & & & 2.78 \\
\hline
\end{tabular}

high is around $95 \%$, while for dams $5 \mathrm{~m}$ high, attenuation is around $80 \%$. A similar behavior was also observed by Fread \& Lewis (1998), who showed abrupt hydrographs, with large peak flows and short times to reach the peak, can experience considerable attenuation when passing through wide floodplains.

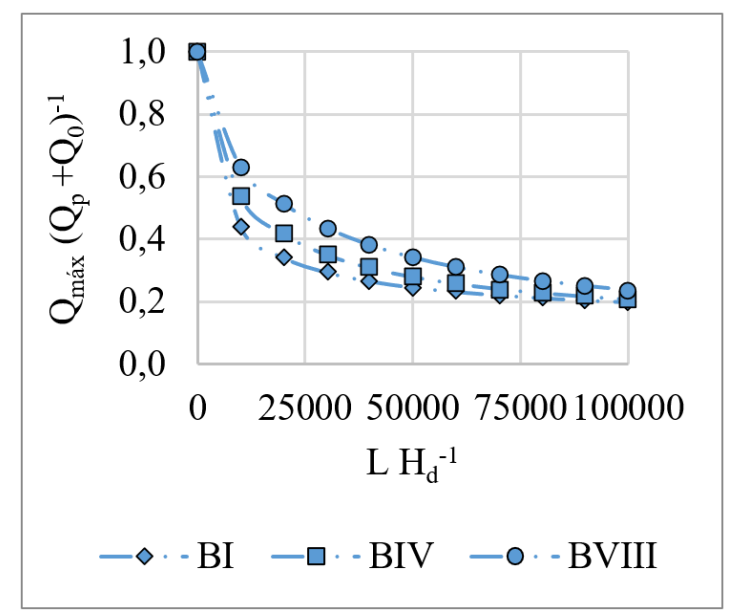

Figure 4. Peak flow attenuation through the downstream channel $-5 \mathrm{~m}$ dams.

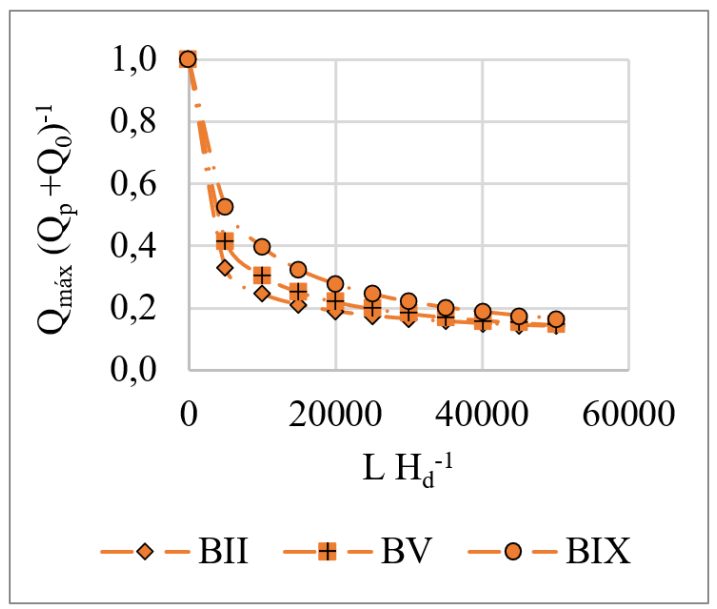

Figure 5. Peak flow attenuation through the downstream channel - $10 \mathrm{~m}$ dams.

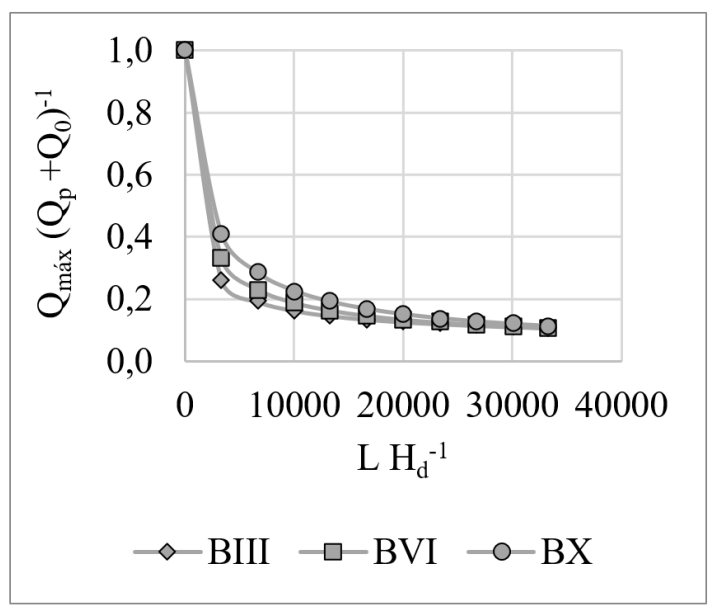

Figure 6. Peak flow attenuation through the downstream channel - $15 \mathrm{~m}$ dams. 


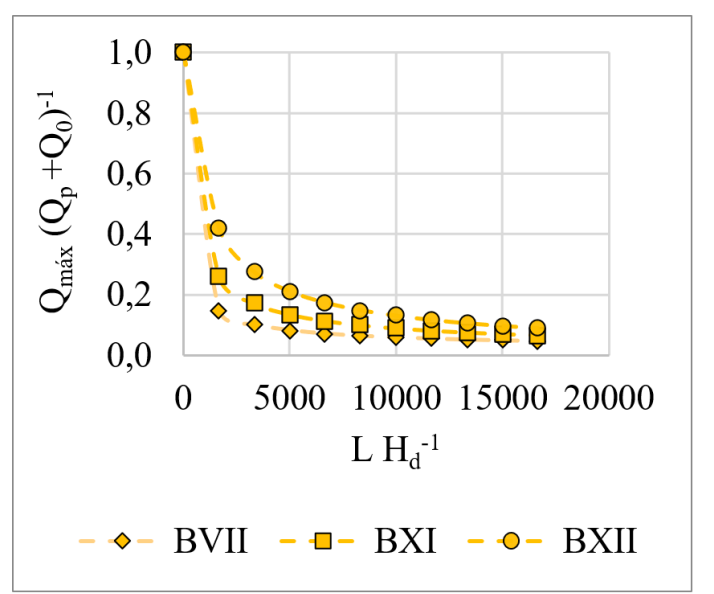

Figure 7. Peak flow attenuation through the downstream channel - $30 \mathrm{~m}$ dams.

After verifying that all flow attenuation curves present an exponential decay, an attempt was made to find an equation to describe this behavior, which lead to Equation 9:

$\frac{\mathrm{Q}_{\text {máx }}}{\left(\mathrm{Q}_{\mathrm{p}}+\mathrm{Q}_{0}\right)}=\left(1+\mathrm{a} \frac{\mathrm{L}}{\mathrm{H}_{\mathrm{d}}}\right)^{\frac{-1}{\mathrm{~b}}}$

Where: $\mathrm{Q}_{\text {max }}$ is the maximum discharge in a specific section $\left(\mathrm{m}^{3} \mathrm{~s}^{-1}\right)$; $Q_{p}$ is the rupture peak flow $\left(\mathrm{m}^{3} \mathrm{~s}^{-1}\right) ; \mathrm{Q}_{0}$ is the downstream valley base flow $\left(\mathrm{m}^{3} \mathrm{~s}^{-1}\right)$; $\mathrm{L}$ is the distance from the dam section $(\mathrm{m})$; $\mathrm{H}_{\mathrm{d}}$ is the dam height (m); "a" and " $\mathrm{b}$ " are equation parameters.

Figure 8 and Figure 9 present the behavior of parameters "a" and "b" of Equation 9 for each of the dams, based on a dimensionless index that allows differentiation of each of the dams according to their volume and height $\left(\mathrm{V}_{\mathrm{r}}^{(1 / 3)} \mathrm{H}_{\mathrm{d}}^{-1}\right)$.

Analyzing the relationship of each parameter of the proposed equation with $\mathrm{V}_{\mathrm{r}}^{(1 / 3)} \mathrm{H}_{\mathrm{d}}{ }^{-1}$, two types of behavior are perceived: both parameters present a similar trend for dams of same height; and a unique trend is observed for parameter "a", independent of dam height or volume. Based on these behaviors, equations were adjusted, for each group of dams, to describe the relation of parameters "a" and " $b$ " with $\mathrm{V}_{r}^{(1 / 3)} \mathrm{H}_{\mathrm{d}}{ }^{-1}$. These equations are presented in Table 8 and Table 9.

Within the intervals used in the equations' deduction, the use of Equation 9 for dams with different heights and volumes becomes possible by interpolating from the presented regression curves. Thereby, starting from basic information, such as the characteristics of a dam, and calculating the maximum rupture flow with the existing methodologies, obtaining an estimate of maximum flows in any downstream valley cross section becomes feasible.

\section{Peak discharge arrival time}

A dimensionless variable was established for the peak discharge arrival time analysis. It relates the arrival time of flood wave peak, maximum flow in each section and reservoir's volume at the time of rupture $\left(\mathrm{t}_{\mathrm{c}} \mathrm{Q}_{\text {maxx }} \mathrm{V}_{\mathrm{r}}^{-1}\right)$. Having some sort of simplified

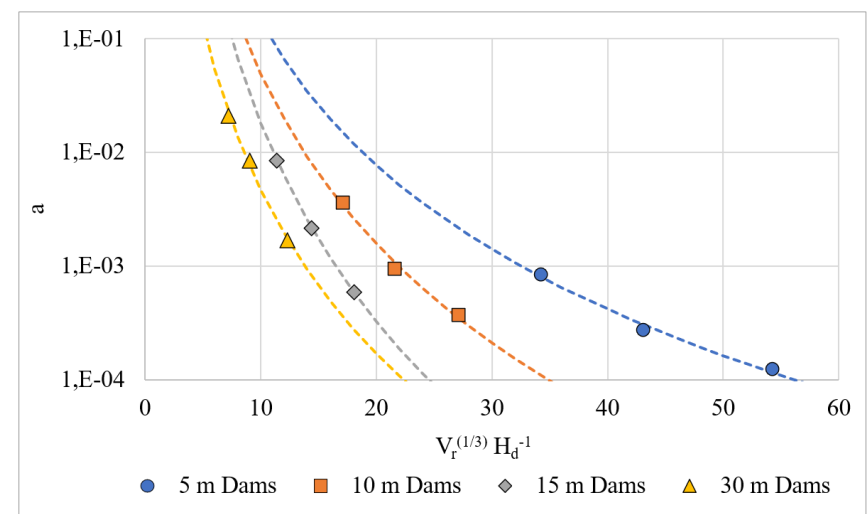

Figure 8. Behavior of parameter " $\mathrm{a}$ " as a function of $\mathrm{V}_{\mathrm{r}}^{(1 / 3)} \mathrm{H}_{\mathrm{d}}^{-1}$.

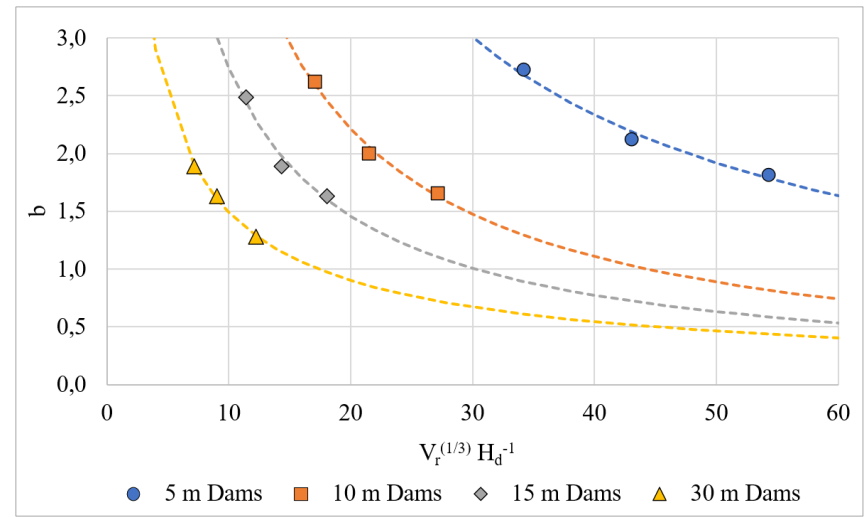

Figure 9. Behavior of parameter " $b$ " as a function of $\mathrm{V}_{\mathrm{r}}^{(1 / 3)} \mathrm{H}_{\mathrm{d}}^{-1}$.

Table 8. Equations of parameter " $a$ " as a function of the dimensionless variable that characterizes the dam.

\begin{tabular}{cccc}
\hline $\mathbf{H}_{\mathrm{d}}(\mathrm{m})$ & Equations for $\mathbf{a}$ & Eq. $\mathbf{n}^{\mathbf{0}}$ & $\mathbf{R}^{2}$ \\
\hline 5 & $\mathrm{a}=2302\left(\frac{\mathrm{V}_{\mathrm{r}}^{1 / 3}}{\mathrm{H}_{\mathrm{d}}}\right)^{-4.207}$ & $(10)$ & 0.98 \\
10 & $\mathrm{a}=4432.2\left(\frac{\mathrm{V}_{\mathrm{r}}^{1 / 3}}{\mathrm{H}_{\mathrm{d}}}\right)^{-4.957}$ & $(11)$ & 0.99 \\
15 & $\mathrm{a}=11203.0\left(\frac{\mathrm{V}_{\mathrm{r}}^{1 / 3}}{\mathrm{H}_{\mathrm{d}}}\right)^{-5.792}$ & $(12)$ & 0.97 \\
30 & $\mathrm{a}=276.6\left(\frac{\mathrm{V}_{\mathrm{r}}^{1 / 3}}{\mathrm{H}_{\mathrm{d}}}\right)^{-4.772}$ &
\end{tabular}

approach to describe this dimensionless variable behavior would result in a useful tool for estimating the required time for the flood wave to reach its most critical level.

Based on simulation results, Figures 10-13 show the hereby considered dimensionless variable evolution for all studied dams' groups. As expected, a positive trend is observed as dam distance along the valley increases. This may be explained by the evident fact that peak discharge arrival time increases with 


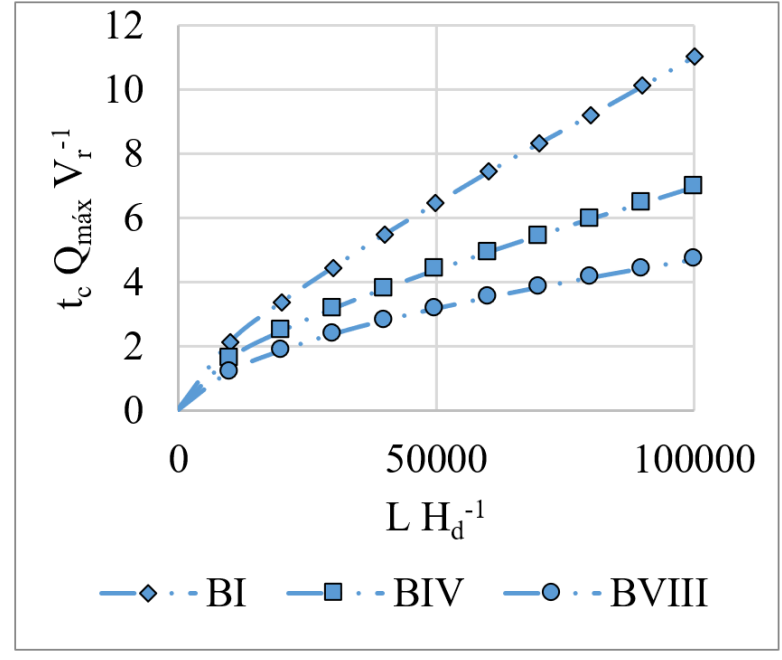

Figure 10. Dimensionless relation of the arrival time of the peak discharge - $5 \mathrm{~m}$ dams.

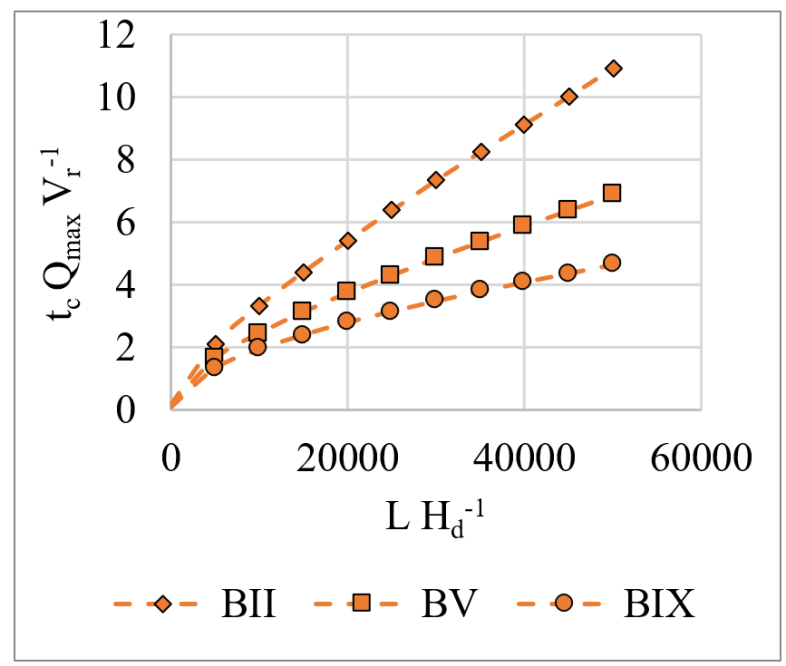

Figure 11. Dimensionless relation of the arrival time of the peak discharge - $10 \mathrm{~m}$ dams.

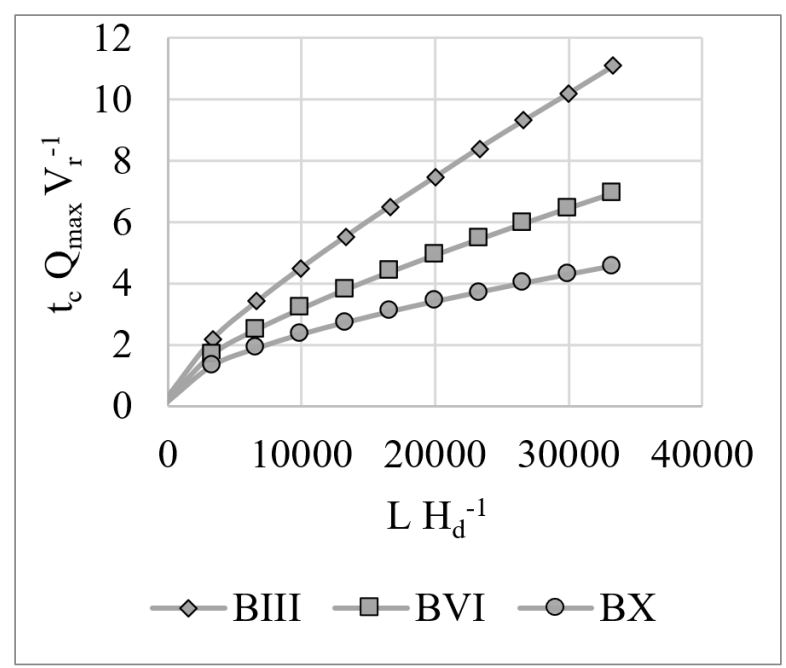

Figure 12. Dimensionless relation of the arrival time of the peak discharge - $15 \mathrm{~m}$ dams.

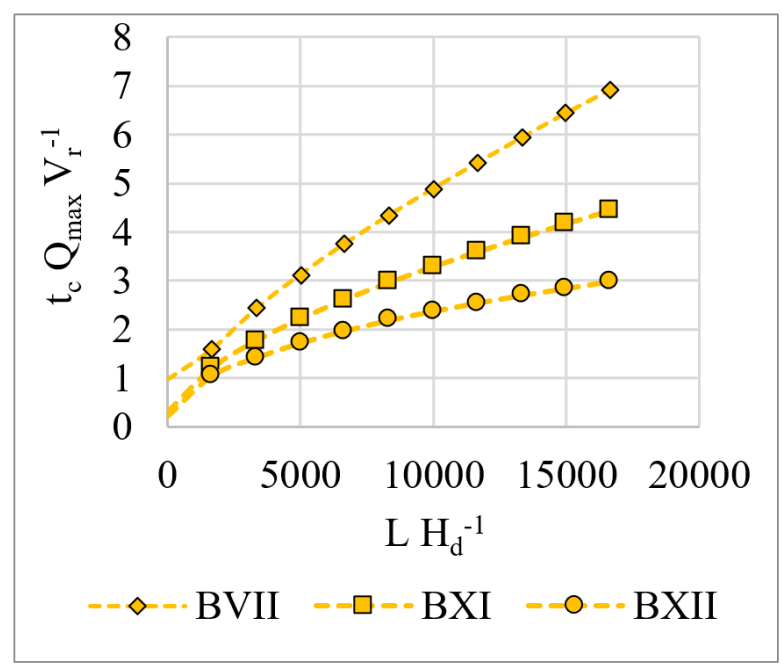

Figure 13. Dimensionless relation of the arrival time of the peak discharge - $30 \mathrm{~m}$ dams.

Table 9. Equations of parameter " $b$ " as a function of the dimensionless variable that characterizes the dam.

\begin{tabular}{cccc}
\hline $\mathbf{H}_{\mathbf{d}}(\mathrm{m})$ & Equation for $\mathbf{b}$ & $\mathbf{E q} \cdot \mathbf{n}^{\mathbf{0}}$ & $\mathbf{R}^{2}$ \\
\hline 5 & $\mathrm{~b}=59.789\left(\frac{\mathrm{V}_{\mathrm{r}}^{1 / 3}}{\mathrm{H}_{\mathrm{d}}}\right)^{-0.879}$ & $(14)$ & 0.98 \\
10 & $\mathrm{~b}=43.706\left(\frac{\mathrm{V}_{\mathrm{r}}^{1 / 3}}{\mathrm{H}_{\mathrm{d}}}\right)^{-0.996}$ & $(15)$ & 0.99 \\
15 & $\mathrm{~b}=22.342\left(\frac{\mathrm{V}_{\mathrm{r}}^{1 / 3}}{\mathrm{H}_{\mathrm{d}}}\right)^{-0.911}$ & $(16)$ & 0.97 \\
30 & $\mathrm{~b}=7.926\left(\frac{\mathrm{V}_{\mathrm{r}}^{1 / 3}}{\mathrm{H}_{\mathrm{d}}}\right)^{-0,725}$ & $(17)$ & 0.99 \\
\hline
\end{tabular}

distance, any influence from other parameters being very small. The observed relationship variation between maximum discharge $\left(\mathrm{Q}_{\max }\right)$ and reservoir volume at rupture $\left(\mathrm{V}_{\mathrm{r}}\right)$ is not significant because of the volumes' magnitude. Therefore, the behavior of the dimensionless variable $\left(t_{c} Q_{\text {máx }} V_{r}^{-1}\right)$ is mostly ruled by the time parameter. Additionally, in all groups, the larger the dam (largest both in height and volume) the smaller the magnitude of the dimensionless variable. This occurs because, the channel being the same for all analyzed cases, the higher the discharge, the larger the flow velocity and, consequently, the shorter the time to reach the most critical hydraulic situation. The results also showed that magnitude of the dimensionless variable is similar for dams of the same volume (BI, BII and BIII; BIV, BV and BVI).

The dimensionless variable behavior concerning peak discharge arrival time resembles a potential curve. A process of results best fit regression enabled the deduction of Equation 18, which shall be used for $\mathrm{LH}_{\mathrm{d}}^{-1}>0$ to prevent null calculated time (physically impossible). For $\mathrm{LH}_{\mathrm{d}}^{-1}=0$, peak discharge arrival time 


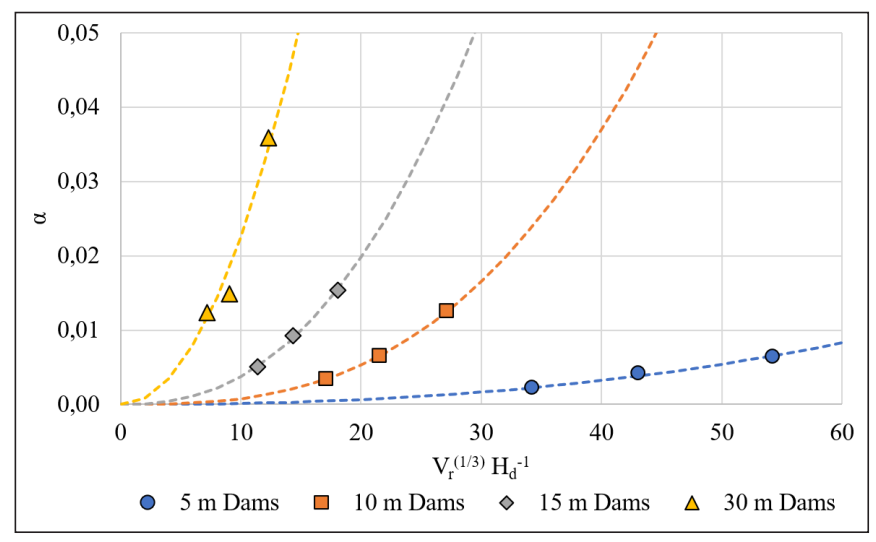

Figure 14. Behavior of parameter $\alpha$ as a function of $\mathrm{V}_{\mathrm{r}}^{(1 / 3)} \mathrm{H}_{\mathrm{d}}^{-1}$.

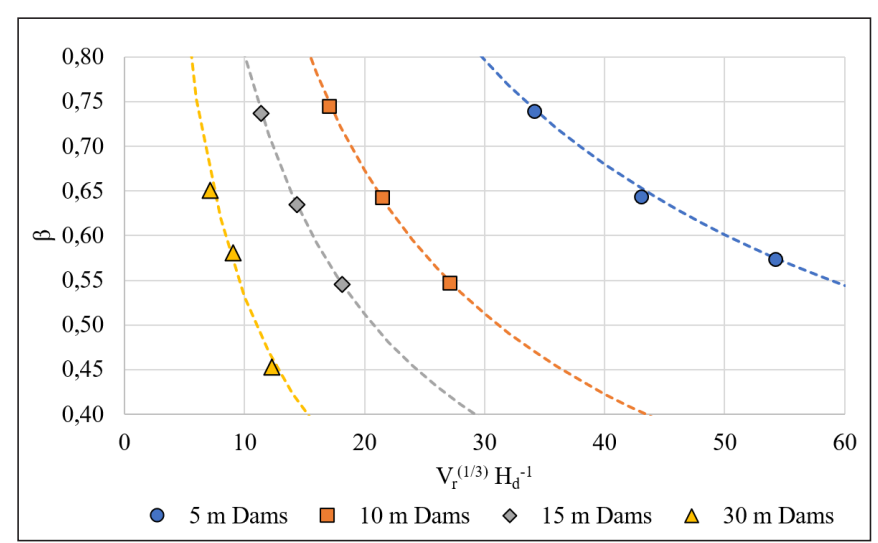

Figure 15. Behavior of parameter $\beta$ as a function of $\mathrm{V}_{\mathrm{r}}^{(1 / 3)} \mathrm{H}_{\mathrm{d}}^{-1}$.

corresponds to the peak time of breach hydrograph, calculated with existing methods as already described.

Therefore, for $\mathrm{LH}_{\mathrm{d}}^{-1}>0$ :

$\frac{t_{c} Q_{\text {máx }}}{V_{r}}=\alpha\left(\frac{L}{H_{d}}\right)^{\beta}$

Where: $\mathrm{t}_{\mathrm{c}}$ is the peak discharge arrival time $(\mathrm{s}) ; \mathrm{Q}_{\text {máx }}$ is the maximum discharge in a specific section $\left(\mathrm{m}^{3} / \mathrm{s}\right) ; \mathrm{V}_{\mathrm{r}}$ is the reservoir's volume $\left(\mathrm{m}^{3}\right)$; $\mathrm{L}$ is the distance from the dam section $(\mathrm{m}) ; \mathrm{H}_{\mathrm{d}}$ is the dam height $(\mathrm{m}) ; \alpha$ and $\beta$ are equation parameters.

The relationships between parameters ( $\alpha$ and $\beta$ ) of Equation 18 and dimensionless variable $\mathrm{V}_{\mathrm{r}}^{(1 / 3)} \mathrm{H}_{\mathrm{d}}^{-1}$ is graphically shown in Figure 14 and Figure 15. They evidence different behaviors for each dam height, similarly to what was observed for peak flow attenuation. Thus, equations have been proposed to characterize this behavior, as shown in Table 10 and Table 11.

The proposed equations in these tables allow the use of Equation 18 in conjunction with Equation 9, both requiring very few input data while providing means for estimating the required time for the most critical hydraulic conditions to be reached. This represents a considerable progress due to its expediency and ease of use, being rather innovative regarding dam rupture flood wave characteristics assessment based on simplified methods.
Table 10. Equations of parameter $\alpha$ as a function of the dimensionless variable that characterizes the dam.

\begin{tabular}{cccc}
\hline $\mathbf{H}_{\mathrm{d}}(\mathrm{m})$ & Equations for $\alpha$ & Eq. $\mathbf{n}^{\mathrm{o}}$ & $\mathbf{R}^{2}$ \\
\hline 5 & $\alpha=\left(6.00010^{-7}\right)\left(\frac{\mathrm{V}_{\mathrm{r}}^{1 / 3}}{\mathrm{H}_{\mathrm{d}}}\right)^{2.3277}$ & $(19)$ & 0.99 \\
10 & $\alpha=\left(1.21210^{-6}\right)\left(\frac{\mathrm{V}_{\mathrm{r}}^{1 / 3}}{\mathrm{H}_{\mathrm{d}}}\right)^{2.7989}$ & $(20)$ & 1.00 \\
15 & $\alpha=\left(1.52910^{-5}\right)\left(\frac{\mathrm{V}_{\mathrm{r}}^{1 / 3}}{\mathrm{H}_{\mathrm{d}}}\right)^{2.3921}$ & \\
30 & $\alpha=\left(2.04810^{-4}\right)\left(\frac{\mathrm{V}_{\mathrm{r}}^{1 / 3}}{\mathrm{H}_{\mathrm{d}}}\right)^{2.0415}$ &
\end{tabular}

Table 11. Equations of parameter $\beta$ as a function of the dimensionless variable that characterizes the dam.

\begin{tabular}{cccc}
\hline $\mathbf{H}_{\mathrm{d}}(\mathrm{m})$ & Equations for $\beta$ & Eq. $\mathbf{n}^{\mathbf{0}}$ & $\mathbf{R}^{2}$ \\
\hline 5 & $\beta=5.1713\left(\frac{\mathrm{V}_{\mathrm{r}}^{1 / 3}}{\mathrm{H}_{\mathrm{d}}}\right)^{-0.55}$ & $(23)$ & 0.99 \\
10 & $\beta=5.0066\left(\frac{\mathrm{V}_{\mathrm{r}}^{1 / 3}}{\mathrm{H}_{\mathrm{d}}}\right)^{-0.67}$ & $(24)$ & 0.99 \\
15 & $\beta=3.5859\left(\frac{\mathrm{V}_{\mathrm{r}}^{1 / 3}}{\mathrm{H}_{\mathrm{d}}}\right)^{-0.65}$ & $(25)$ & 1.00 \\
30 & $\beta=2.5466\left(\frac{\mathrm{V}_{\mathrm{r}}^{1 / 3}}{\mathrm{H}_{\mathrm{d}}}\right)^{-0.68}$ & & \\
& & & \\
\hline
\end{tabular}

\section{Case study}

A case study is presented in which results obtained from the hydrodynamic simulations (reference scenario) are compared with those obtained from simplified methods according the following criteria:

- Maximum discharges: calculated for each cross section by Equation 9 and by the Simplified Dam-Break Flood Modeling (Melo, 2015) method;

- Water heights: calculated using Manning's equation combined with maximum discharges obtained in each of the simplified approaches. Since there are different roughness coefficient values for the main channel and the outer banks' area, a mean between both coefficients was adopted; 
- Peak discharge arrival time: calculated using Equation 18 combined with the maximum discharges obtained in each of the simplified approaches, as described in the item of the present case study.

Table 12 presents the peak outflows calculated with equations from Froehlich (1995), Webby (1996), Azimi et al. (2015) and Ferla (2018), while Table 13 presents the time to reach the peak outflow calculated with the equations from Bureau of Reclamation (1988) and Von Thun \& Gillette (1990). Based on the dam characteristics, the most critical breach output hydrograph (Figure 16) was obtained with peak outflow calculated with Azimi et al. (2015) equation and time to reach the peak calculated with Von Thun \& Gillette (1990) equation for erodible materials. In order to proceed with the dam-break analysis in the downstream valley, the estimated rupture hydrograph must be added to the base flow (initial condition $\left.-\mathrm{Q}_{0}=1.098 \mathrm{~m}^{3} \mathrm{~s}^{-1}\right)$.

\section{a) Maximum discharges}

Maximum discharges calculated in the numerical simulations, as well as discharges estimated by Equation 9 and using Melo (2015) method, are presented in Figure 17.

The maximum discharges over downstream valley entire length provided by Equation 9 lead to a conservative scenario, since they are, on average, 15\% higher than corresponding discharges obtained by computer simulation. Considering the tendency presented by the method, possibly further downstream of last studied cross section $(43 \mathrm{~km}$ downstream from the dam section) estimated discharges using Equation 9 are closer to the ones obtained through computational simulation.

The simplified method of Melo (2015) provided a scenario in favor of safety until a section $23 \mathrm{~km}$ downstream from the dam. Past that section, estimated discharges are below those obtained through computational simulations. Over the first $23 \mathrm{~km}$ of the valley, maximum discharges are, on average, $7.8 \%$ above simulations' results.

\section{b) Water heights}

Water heights obtained by the simulations as well as the ones calculated combining Manning equation with Equation 9, and Melo's method (Melo, 2015), are presented in Figure 18.

Similarly to what was observed for discharges, water heights obtained from discharges estimated using Equation 9 are higher throughout the entire downstream valley than those obtained by the numerical simulations. Average relative error between flows is approximately $8 \%$. Along the valley, maximum and minimum differences between water heights are, respectively, 0.61 and $0.20 \mathrm{~m}$. Results comparison shows the use of hereby proposed approach provides conservative results, although quite close to the reference scenario.

Melo (2015) simplified approach estimates water heights above those from HEC-RAS up to a distance of $23 \mathrm{~km}$ from the dam section. Although water heights in this stretch with the simplified approach exceed the numerical simulation, maximum difference is $0.50 \mathrm{~m}$. From that section on, maximum difference increases to $0.69 \mathrm{~m}$.
Table 12. Peak outflow $\left(\mathrm{m}^{3} \mathrm{~s}^{-1}\right)$ calculated for the studied dam.

\begin{tabular}{cccc}
\hline $\begin{array}{c}\text { Froehlich } \\
\mathbf{( 1 9 9 5 )}\end{array}$ & $\begin{array}{c}\text { Webby } \\
\mathbf{( 1 9 9 6 )}\end{array}$ & $\begin{array}{c}\text { Azimi et al. } \\
\mathbf{( 2 0 1 5 )}\end{array}$ & $\begin{array}{c}\text { Ferla } \\
\mathbf{( 2 0 1 8 )}\end{array}$ \\
\hline 2,398 & 2,753 & 3,248 & 2,739 \\
\hline
\end{tabular}

Table 13. Time to reach the peak (h) calculated for the studied dam.

\begin{tabular}{ccc}
\hline \multirow{2}{*}{$\begin{array}{c}\text { Bureau of } \\
\text { Reclamation (1988) }\end{array}$} & \multicolumn{2}{c}{ Von Thun \& Gillette (1990) } \\
\cline { 2 - 3 } & $\begin{array}{c}\text { Resistant to } \\
\text { erosion }\end{array}$ & $\begin{array}{c}\text { Erodible } \\
\text { materials }\end{array}$ \\
\hline 0.50 & 0.55 & 0.23 \\
\hline
\end{tabular}

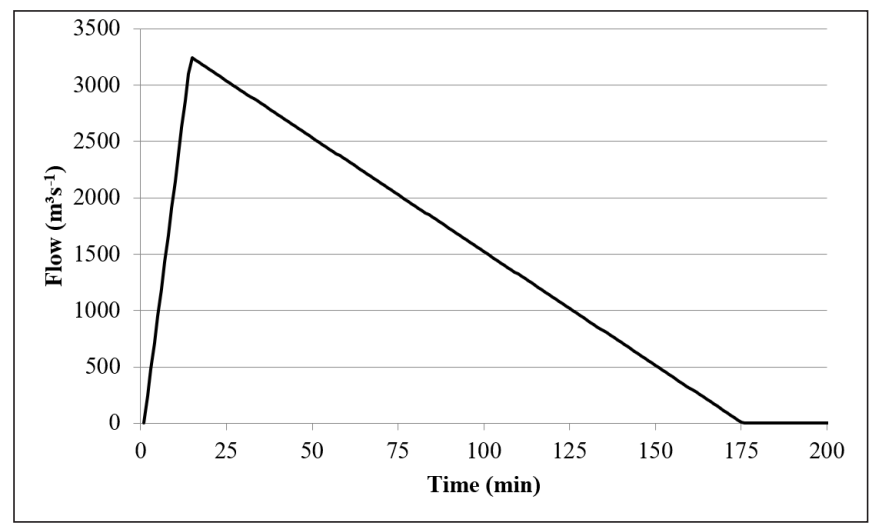

Figure 16. Case study breach outflow hydrograph.

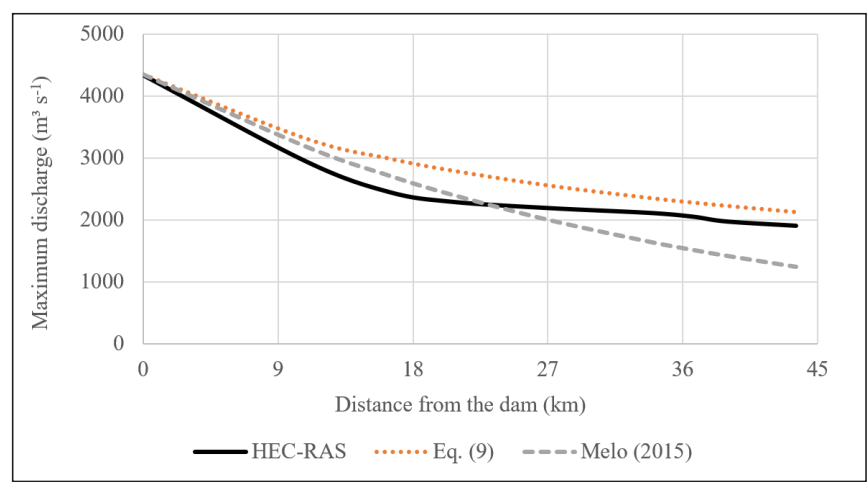

Figure 17. Maximum discharges throughout the downstream valley.

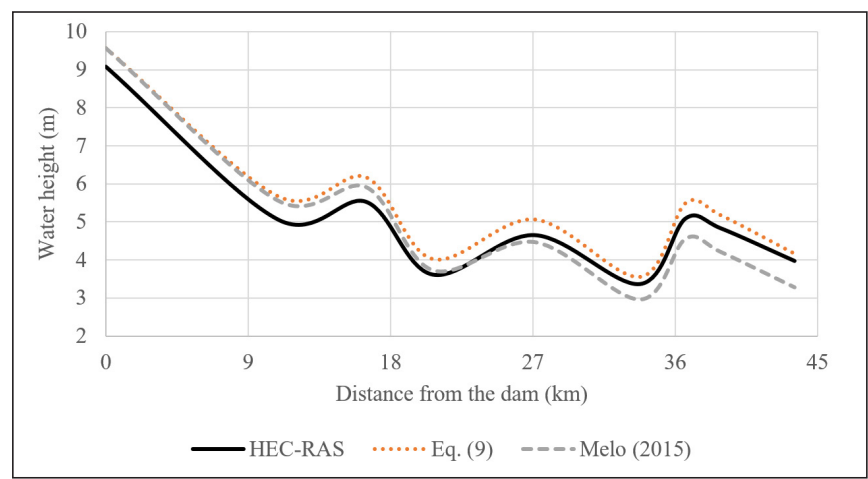

Figure 18. Water heights throughout the downstream valley. 


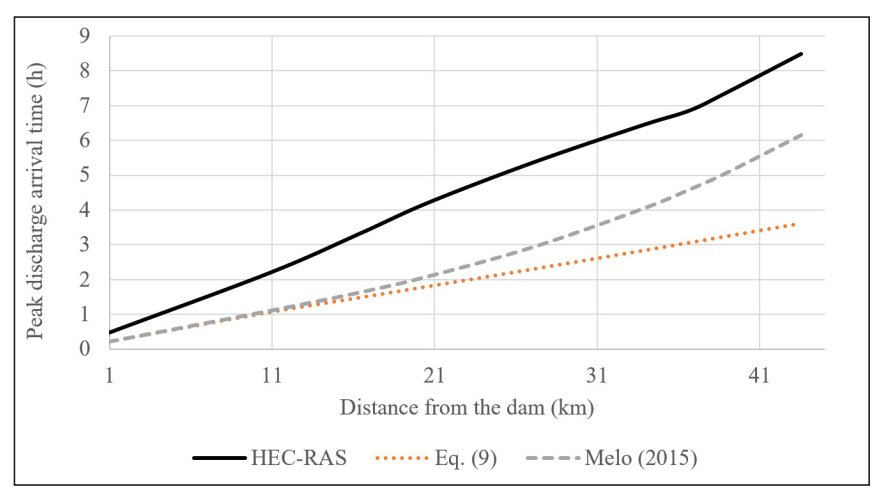

Figure 19. Arrival time of the peak discharge throughout the downstream valley.

\section{c) Peak discharge arrival time of the}

Peak discharge arrival times obtained by the simulations as well as the ones calculated by the combination of Equation 18 with Equation 9, and Melo's method (Melo, 2015), are presented in Figure 19.

Both simplified methods underestimate peak discharge arrival time, a conservative scenario being, therefore, produced. This behavior can be justified by the fact that Equation 18 does not consider storage effects, since it was derived assuming a channel where its cross sections do not allow the simulation of such aspect.

\section{CONCLUSIONS}

The paper's main objective is to present a simplified approach to evaluate dam failures flood waves characteristics, specifically peak flow attenuation and peak discharges arrival times along dam's downstream valleys. Those aspects were selected because, if one can estimate these parameters, then other key aspects for assessing dam ruptures consequences can be derived from them. Nevertheless, as other simplified methods, this approach cannot be used directly in the elaboration of high-risk dams' EAPs. On the other hand, it can be applied in situations such as dam-break studies pre-assessment phases or definition of dams' associated potential hazard.

To achieve this goal, simulations of hypothetical dam ruptures were carried out with the HEC-RAS 1D software based on simplified rupture hydrograph routing strategy, as normally considered in most simplified methods. These methods are normally based on scarce and inaccurate empirical data from past dam failures and, for that reason, should always be applied considering conservative hypothesis. On the other hand, the usual procedure to evaluate dam failures effects consists on performing simulations with software that solve the Saint Venant's equations. Judiciously combining these two approaches for a set of predefined hypothetical dams covering most common practical situations in terms of dam sizes can, therefore, be a promising way of enhancing the use of simplified approaches.

For the development of the hereby proposed simplified method, twelve different size hypothetical dams were studied, considering the size criteria proposed by Agência Nacional de Águas (2016b). For each of these dams, the most critical cases were studied in order to provide an approach leading to results with a certain safety margin. Breach hydrographs of each dam were routed in a fictitious uniform trapezoidal channel, $500 \mathrm{~km}$ in length with constant slope $\left(0.001 \mathrm{~m} \mathrm{~m}^{-1}\right)$.

From simulations' results, equations were empirically deduced describing the behavior of each studied flow parameter. For peak flow attenuation, Equation 9 was defined describing a potential decay behavior. Peak discharge arrival time was described using Equation 18, being noteworthy that it shall be considered only for $\mathrm{L} \mathrm{H}_{\mathrm{d}}^{-1}>0$.

In order to assess the simplified methods' efficiency when compared with more complex models, a case study was analyzed considering a real topobatimetry and a hypothetical $15 \mathrm{~m}$ high dam with $17 \mathrm{hm}^{3}$ of reservoir volume. An average $0.0008 \mathrm{~m} \mathrm{~m}^{-1}$ slope downstream valley topobatimetry was assumed, close to that used for the simplified approach development, presented in this paper. In addition, the case study considered characteristics that fall within the range of dam sizes adopted for the research. The evaluated simplified methods correspond to the set of equations proposed in this paper and to the method proposed in Melo (2015). The parameters evaluated in the case study are: maximum discharge, water height and peak discharge arrival time. The case study reiterates the simplified methods applicability, since results are close to the ones from hydrodynamic simulations. Additionally, the case study results presented a better performance for maximum discharges and water heights using Equation 9 rather than the method proposed in Melo (2015). The proposed approach provides conservative results, but reasonably close to those obtained by hydrodynamic simulations: the average difference is $15 \%$ for discharge and over $8 \%$ for water height. Differently, all the simplified methods underestimated the flood wave peak arrival times by approximately $50 \%$, which, for this specific aspect, translates into a conservative result.

According to Melo et al. (2015), classification concerning potential damage and associated risk is the main objective of simplified methodologies. Therefore, any method that makes it possible to estimate maximum water levels resulting from a rupture in predefined sections downstream of a dam meets the requirements. Despite considering very limited information (height and volume of the reservoir), the proposed simplified approach enables an assessment of important aspects of the rupture at any downstream valley section, from which maximum water levels can be obtained, fitting Melo's description.

It must be highlighted that the proposed approach in the present paper still requires further testing involving additional case studies and further enhancements by expanding dam characteristics range. This will enable broadening of hereby proposed equations applicability range. On that note, in addition to increasing the database of dam characteristics, applying the same strategy to channels with different slopes and roughnesses, as well as with sections of different geometries and areas, is recommended. Doing so, the influence of roughness and topography can be added into the method. These improvements will allow a more complete set of equations for dam-break flood consequences assessment. However, for now, it also must be emphasized that the application of this approach is limited to similar conditions of those used in its elaboration. 


\section{AKNOWLEDGEMENTS}

This study was sponsored by Conselho Nacional de Desenvolvimento Científico e Tecnológico (CNPq).

\section{REFERENCES}

Agência Nacional de Águas - ANA. (2016a). Manual do Empreendedor sobre Segurança de Barragens Volume IV: Guia de Orientação e Formulários do Plano de Ação de Emergência - PAE. Brasília, DF: ANA.

Agência Nacional de Águas - ANA. (2016b). Manual do Empreendedor sobre segurança de Barragens Volume III: Guia de Revisão Periódica de Segurança de Barragens. Brasília, DF: ANA.

Agência Nacional de Águas - ANA. (2017). Relatório de Segurança de Barragens. Brasília, DF: ANA.

Alvarez, M., Puertas, J., Peña, E., \& Bermudez, M. (2017). Twodimensional dam-break flood analysis in data-scarce regions: the case study of Chipembe Dam, Mozambique. Water (Basel), 9(6), 432. http://dx.doi.org/10.3390/w9060432.

Arab News. (2020, August 02). 'Hundreds' of homes destroyed after Sudan dam collapse. Arab News. Retrieved in 2020, August 5, from https://www.arabnews.com/node/1713711/middle-east

Azimi, R., Vatankhah, A. R., \& Kouchakzadeh, S. (2015). Predicting peak discharge from breached embankment dams. 36th IAHR World Congress, Hague, Netherlands.

Bates, P. D., \& De Roo, A. P. J. (2000). A simple raster-based model for floodplain inundation. Journal of Hydrology (Amsterdam), 236(12), 54-77. http://dx.doi.org/10.1016/S0022-1694(00)00278-X.

Bureau of Reclamation (1988). Downstream hazard classification guidelines. ACER Tech. Memorandum No. 11, U.S. Department of the Interior, Bureau of Reclamation, Denver, 57.

Cunge, J. A. (1969). On the subject of a flood propagation computation method (Muskingum method). J. Hydrol. Res., 7(2), 205-230. http://dx.doi.org/10.1080/00221686909500264.

Elisa, T., \& Campos, C. (2020, Maio 31). Barragem se rompe na zona rural de Perdizes. G1. Retrieved in 2020, June 11, from https://g1.globo.com/mg/triangulo-mineiro/noticia/2020/05/31/ rompimento-de-acude-e-registrado-na-zona-rural-de-perdizesneste-domingo.ghtml

Ellison, G. (2020). Edenville Dam failure investigation to take 'many months'. MLive. Accessed in August 5th, 2020, from https://www.mlive.com/news/2020/06/edenville-dam-failureinvestigation-to-take-many-months.html

Federal Emergency Management Agency - FEMA. (2001). The National Dam Safety Program - Research needs workshop: Hydrologic issues for dams. Denver, Colorado: FEMA.

Ferla, R. (2018). Análise de aspectos bidráulicos de métodos simplificados envolvendo rompimento de barragens. Porto Alegre: UFRGS.
Ferla, R., Priebe, P. S., Novakoski, C. K., Hampe, R. F., Saliba, A. P. M., Teixeira, E. D., \& Marques, M. G. (2017). Utilização de diferentes equações empíricas na previsão de características de inundação proveniente do rompimento de barragens. Simpósio de Hidráulica e Recursos Hidricos dos Países de Lingua Portuguesa (SILUSBA), Porto, Portugal: APRH.

Ferretti, C. (2020, August 9). Minor damage expected from partial breach of Hillsdale County dam. The Detroit News. Accessed in 2020, August 5, from https://www.detroitnews.com/story/news/ local/michigan/2020/08/09/minor-damage-expected-partialbreach-hillsdale-county-dam/3331548001/

Fread, D. L. (1991). The NWS DAMBRK model: Theoretical backeground/ User documentation (123 p.). Silver Spring, MD: Hydrologic Research Laboratory, Office of Hydrology, National Weather Service, NOAA.

Fread, D. L., \& Lewis, J. M. (1998). NWS FLDWAV Model: Theoretical description and user documentation (335 p.). Silver Spring, MD: Hydrologic Research Laboratory, Office of Hydrology, National Weather Service, NOAA.

Froehlich, D. C. (1995). Peak outflow from breached embankment dam. Journal of Water Resources Planning and Management, 121(1), 9097. http://dx.doi.org/10.1061/(ASCE)0733-9496(1995)121:1(90).

Froehlich, D. C. (2016). Predicting peak discharge from gradually breached embankment dam. Journal of Hydrologic Engineering, 21(11), 04016041. http://dx.doi.org/10.1061/(ASCE)HE.19435584.0001424 .

G1 Caruaru (2020, Junho 15). Barragem se rompe em Sairé e água invade casas em Barra de Guabiraba. G1. Accessed in 2020, August 5, from https://g1.globo.com/pe/caruaru-regiao/ noticia/2020/06/15/barragem-rompe-em-saire-e-agua-invadecasas-em-barra-de-guabiraba.ghtml

Grimaldi, S., \& Poggi, D. (2010). A synthetic method for assessing the risk of dam flooding. 78th International Commission on Large Dams Annual Meeting. Hanoi, Vietnã: ICOLD.

Hooshyaripor, F., Tahershamsi, A., \& Razi, S. (2017). Dam break flood wave under different reservoir's capacities and lengths. Sadhana, 42(9), 1557-1569. http://dx.doi.org/10.1007/s12046-017-0693-x.

Imbrogno, D. F. (2014). Analysis of Dam Failures and Development of a Dam Safety Evaluation Program (Doctoral dissertation). Ohio State University, Ohio.

Jansen, R. B. (1983). Dams and Public Safety. Denver, CO: US Departament of Interior, Bureau of Reclamation.

Kim, B., \& Sanders, B. F. (2016). Dam-break flood model uncertainty assessment: case study of extreme flooding with multiple dam failures in Gangneung, South Korea. Journal of Hydraulic Engineering, 142(5), 05016002. http://dx.doi.org/10.1061/(ASCE)HY.19437900.0001097.

Kuhlkamp, J. F. (2016). Análise do efeito em cascata da propagação da onda de cheia gerada pelo rompimento hipotético de uma das barragens existentes no rio Irani-SC. 76 f. (Monografia). Faculdade de Engenharia Civil, Universidade Federal de Santa Catarina, Florianópolis. 
Laboratório Nacional de Engenharia Civil - LNEC. (2014). Serviços Analiticos e Consultivos em Segurança de Barragens: Produto 6 - Classificação de Barragens Reguladas pela Agência Nacional de Água (Contrato N051/ $A N A / 2012)$. Brasília: Banco Mundial.

Matheny, K. (2020, May 22). Sanford Dam also failed, state confirms; GOP calls for AG Dana Nessel's recusal. Detroit Free Press. Retrieved in 2020, August 5, from https://www.freep.com/ story/news/local/michigan/2020/05/22/sanford-dam-michiganflooding/5245255002/

Meio Norte. (2020, Mar 25). Parte de barragem se rompe deixando feridos e carros soterrados no PI. Meio Norte. Retrieved in 2020, June 11, from https://www.meionorte.com/noticias/parte-debarragem-se-rompe-deixando-feridos-e-carros-soterrados-nopi-384935

Melo, J. F. (2015). Simplified "Dam-Break" flood modeling. In 2nd International Dam World Conference (pp. 47-56). Lisboa, Portugal: LNEC.

Melo, J. F., Araújo, L., Oliveira, M., Martins, T., Pinto, M., \& Freitas, P. (2015). Hazard Potential Classification of Dams Using a Simplified Methodology. In 2nd International Dam World Conference (pp. 599-608). Lisboa, Portugal: LNEC.

Rocha, F. F. (2015). Retroanálise da Ruptura da Barragem São Francisco Miraí, Minas Gerais, Brasil. 200 f. (Dissertation). Escola de Engenharia, Universidade Federal de Minas Gerais, Belo Horizonte.

Sampaio, J. A. L. (2016). As deficiências do Plano de Ação Emergencial das Barragens no Brasil. Revista de Engenharia Civil IMED, 12(2), 7-17.

Souza, D. H. C. (2016). Análise probabilistica e de sensibilidade dos parâmetros de um estudo de rompimento hipotético: barragem de terra. 91 f. (Dissertation). Faculdade de Engenharia Civil, Arquitetura e Urbanismo, Universidade Estadual de Campinas, Campinas.

Teixeira, E. D., Smiderle, C. S. D., Goldenfum, J. A., \& Ferla, R. (2016). Avaliação de métodos de propagação de hidrograma proveniente de ruptura hipotética de barragens: Estudo de caso em um trecho de rio. In 21st Seminário Nacional de Grandes Barragens (SNGB).

Tschiedel, A. D. F., \& Paiva, R. C. D. D. (2018). Uncertainty assessment in hydrodynamic modeling of floods generated by dam break. Revista Brasileira de Recursos Hídricos, 23, 1-17. http:/ / dx.doi.org/10.1590/2318-0331.231820170074.

U.S. Army Corps of Engineers - USACE. (1995). HEC-RAS, River Analysis System. Hydraulic Reference Manual. Version 1. Davis, CA: Engineering Center.

U.S. Army Corps of Engineers - USACE. (2014). Using HEC-RAS for Dam-Break Studies. Davis, CA: Engineering Center.

U.S. Army Corps of Engineers - USACE. (2016). HEC-RAS: River Analysis System. 2D Modelling User's Manual. Davis, CA: USACE.
Von Thun, J. L., \& Gillette, D. R. (1990). Guidance on breach parameters. Internal Memorandum, U.S. Dept. of the Interior, Bureau of Reclamation, Denver, 17.

Wahl, T. L. (2004). Uncertainty of predictions of embankment dam breach parameters. Journal of Hydraulic Engineering, 130(5), 389-397. http://dx.doi.org/10.1061/(ASCE)0733-9429(2004)130:5(389).

Wahl, T. L. (2010 June-July). Dam breach modeling - An overview of analysis methods. In 2 nd Joint Federal Interagency Conference, Las Vegas.

Washington State Department of Ecology (2007). Dam safety guidelines: Technical note 1 - Dam break inundation analysis and downstream hazard classification. Olympia, Washington: Department of Ecology.

Webby, M. G. (1996). Discussion of 'Peak outflow from breached embankment dam' by D. C. Froehlich. J. Water Resources Planning and Management, 4(316), 316-317. http://dx.doi.org/10.1061/ (ASCE)0733-9496(1996)122:4(316).

Wetmore, J., \& Fread, D. L. (1981). The NWS Simplified "Dam-Break" Flood Forecasting Model (24 p.). Silver Spring, Maryland: National Weather Service, Office of Hydrology.

Zhang, L. M., Xu, Y., \& Jia, J. S. (2007 October 18-19). Analysis of earth dam failures: A database approach. In 1st International Symposium on Geotechnical Safety \& Risk. China: Tongji University.

\section{Authors contributions}

Carlo Lucca Coutinho Ungaretti Rossi: Performed the methodology, obtained the results, analyzed the obtained data, wrote and revised the text.

Marcelo Giulian Marques: Oriented the research, analyzed the results and contributed with technical notes.

Eder Daniel Teixeira: Co-oriented the research, analyzed the results and contributed with technical notes.

José Falcão de Melo: Contributed with technical notes and revised the text.

Rute Ferla: Contributed with technical notes and revised the text.

Maurício Dai Prá: Contributed with technical notes and revised the text.

Editor Chefe: Adilson Pinheiro

Editor Associado: Iran Eduardo Lima Neto 